\title{
109. 検者の被ばく低減の検討（骨シンチ製剤投与時について）
}

(Assesment of the Decreasing the Exposure Dose in the Nuclear Medical Working:During Labeling and Injection of Bone Seeking Radiopharmaceutical)

久留米大学病院画像診断センタ久留米大学医学部放射性同位元素施設 久留米大学医学部放射線科
河村誠治、赤峰大介、䗅原 享、近藤富士雄 梅崎典良

石橋正敏、森田誠一郎、早㴊尚文

（はじめに）骨シンチ製剤を、被検者に投与するまでには、ミルキング、標識、分注などの作 業を伴い、それによる手指の被ばくは、検者の被ばく低減を考える上で大きな問題 となっている。今回、シリンジを組み立てるのみで、投与できるシリンジタイプを 臨床に取り入れ、従来タイプと、新タイプを使用した場合における検者の手指被ば く量の検討を行ったので報告する。以後ジェネレーターを使用する方法を（キット タイプ），シリンジを使用する方法を(シリンジタイプ）とする。

（目的）骨シンチ製剤を被検者に投与するまでの、2タイプの作業性の検討と手指被ばく （主な使用機器と薬剤）

量の測定、検討を行うことである。

$$
\begin{aligned}
& \text { ジェネレーター(7. 4GBa)、TLD (MSO-S) } \\
& \text { CCD-F300、AZ-2000、AZ-1600 } \\
& \text { MDP、HMDP }
\end{aligned}
$$

（方法） 1.2タイプの投与までの各過程に要する時間をビデオ映像のタイマーより求めた。

2. TLDにより、2タイプの投与までの各過程における右第二指手掌側被ばく量 の測定を行い検討した。

(結果と考察) 図 1 に、2タイプのセットに要する平均時間を示す。右の 2 列は 1 本のセット 時間を示し、左は6本の時間を示している。6本セットする時シリンジタイプはキッ トタイプの半分以下の時間でセット出来た。図2に、投与までの、各過程において、 右第二指手掌側被ばく量を測定した結果を示す。図3に一週間30人の骨シンチを行 なったと仮定した時の右第二指手掌側被ばく量を示す。図2に示すように、投与まで の各過程における被ばく量を測定し、各過程の被ばく量を認識しておくことは、被ば く量低減の検討を行う上で重要であると考える。また、図3に示すように投与時にお ける被ばく量の割合が最も大きいことから、投与時の手指被ばく量を低減させること が最も重要であると考える。

(まとめ) 1 . シリンシタイプの骨シンチ製剤を使用する ことで、セット時間を短時間化でき、無用の 被ばくを防ぐことができた。

2. 骨シンチ製剤投与までの、各過程における 被ばく量をTLDによる測定で分離して計測 した。

3. 骨シンチ製㓮投与時の被ばくが最も大きく、 この過程の被ばく低減を行うことが今後の課 題と考える。

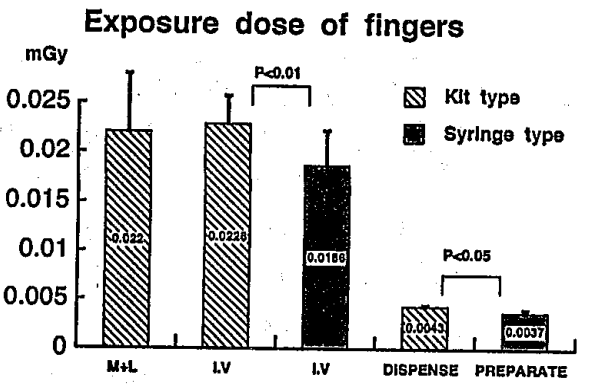

図2

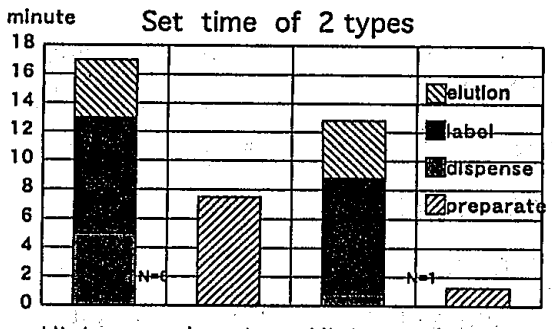

kit type syringe type klt type syringe type 図 1

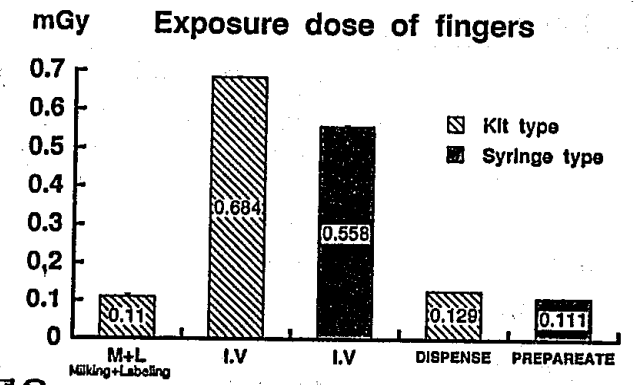
図3 